\title{
Мощные (до 100 Вт) непрерывные лазерные линейки для накачки твердотельных лазеров
}

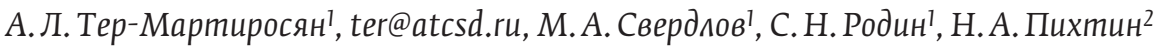 \\ 1 АО «Полупроводниковые приборы", www.atcsd.ru, Санкт-Петербург, Россия \\ 2 ФТИ им. А.Ф.Иоффе, www.ioffe.ru, Санкт-Петербург, Россия
}

\begin{abstract}
Разработаны мощные высокоэффективные непрерывные лазерные линейки, излучающие в спектральном диапазоне 808 нм и предназначенные для накачки твердотельных лазеров. Лазерные линейки имеют высокую эффективность преобразования электрического тока в свет (более 50\%) и малые геометрические размеры. Чипы изготавливаются на основе гетероструктур, полученных методом газофазной эпитаксии из металлорганических соединений (MOCVD). В статье приведены параметры разработанных лл и результаты их ресурсных испытаний.
\end{abstract}

Ключевые слова: лазер полупроводниковый, линейка полупроводниковых лазеров, накачка твердотельных лазеров

\section{Powerful (up to $100 \mathrm{~W}$ ) Continuous Laser Arrays for Pumping Solid-state Lasers}

\author{
A.L.Ter-Martirosyan', ter@atcsd.ru, M.A.Sverdlov', C.N.Rodin', sales@atcsd.ru, N.A.Pikhtin² \\ 3 JSC "Semiconductor devices", St. Petersburg, Russia \\ ${ }^{4}$ Ioffe Institute, St. Petersburg, Russia
}

\begin{abstract}
Powerful high-performance continuous wave (CW) laser arrays, emitting in the spectral range of $808 \mathrm{~nm}$ and designed for pumping solid-state lasers, have been developed. The laser arrays have high efficiency of converting electric current to light (more than 50\%) and small geometrical dimensions. The chips are manufactured based on heterostructures grown by metal organic chemical vapour deposition (MOCVD) epitaxy. The parameters of the developed LA and the results of their life tests are given in the article.
\end{abstract}

Keywords: semiconductor laser, laser arrays, pumping solid-state lasers

Received: 03.06.2019 Accepted: 12.07.2019.

\section{ВВЕДЕНИЕ}

Разработаны мощные высокоэффективные непрерывные лазерные линейки (ЛЛ), излучающие в спектральном диапазоне 808 нм и предназначенные для накачки твердотельных лазеров.

Разработка ЛЛ для систем непрерывной оптической накачки твердотельных лазеров направлена на увеличение эффективности, сни-

\section{INTRODUCTION}

Powerful high-performance continuous wave (CW) laser arrays (LA), emitting in the spectral range of $808 \mathrm{~nm}$ and designed for pumping solid-state lasers, have been developed.

The development of LA for systems of continuous optical pumping of solid-state lasers is aimed at increasing efficiency, reducing energy con- 
жение энергопотребления, уменьшение габа ритов и увеличение срока службы конечных изделий.

Твердотельные лазеры с диодной накачкой, используемые во всем мире для обработки материалов, разделения изотопов, лечения заболеваний, аналитического приборостроения, мониторинга атмосферы, управляемого термоядерного синтеза и военных применений, стремительно вытесняют устаревшие твердотельные лазеры с ламповой накачкой и газовые лазеры. Твердотельные лазеры с диодной накачкой отличаются существенно более высокими КПД, надежностью, лучшими массогабаритными показателями, отсутствием высокого напряжения питания. Во всем мире большинство высокотехнологичных производственных линий используют твердотельные лазеры с диодной накачкой для обработки материалов (резка, сверление отверстий, закалка, подгонка резисторов, гравировка и маркировка). Промышленные лазерные установки для обработки материалов становятся неотъемлемой частью любого высокотехнологичного производства.

Технологические лазеры позволяют существенно увеличить производительность труда, качественно снизить энергопотребление, являются экологически чистым оборудованием. Кроме того, лазерный луч позволяет получить качественно новые результаты (прецизионная обработка, закалка материалов) по сравнению с традиционным оборудованием. Твердотельные лазеры с ламповой накачкой, которыми оснащались производственные линии в течение последних 10-15 лет, наряду с упомянутыми выше преимуществами, имеют существенные недостатки: высокое энергопотребление (низкий КПД), большие габариты и вес, малый срок службы.

В статье приведены параметры разработанных ЛЛ и результаты их ресурсных испытаний.

\section{ХАРАКТЕРИСТИКИ ЛЛ}

В сообщении приводятся результаты разработки энергоэффективных инжекционных ЛЛ нового поколения для систем непрерывной оптической накачки твердотельных лазеров с длиной волны генерации 808 нм, максимальным КПД 55\% и выходной оптической мощностью до 100 Вт.

ЛЛ обеспечивают при температуре $25^{\circ} \mathrm{C}$ следующие основные параметры, представленные в табл. 1.

ЛЛ представляют собой источник лазерного излучения с узкой спектральной линией (3-4 sumption, reducing size and increasing the service life of final products.

Diode-pumped solid-state lasers used all over the world for material processing, isotope separation, disease treatment, analytical instrumentation, atmosphere monitoring, controlled fusion and military applications are rapidly replacing outdated lamp-pumped solid-state lasers and gas lasers. Diode-pumped solid-state lasers are characterized by significantly higher efficiency, reliability, better mass-dimensional parameters, and the absence of a high supply voltage. Around the world, most high-tech production lines use diodepumped solid-state lasers to process materials (cutting, drilling holes, hardening, fitting resistors, engraving and marking). Industrial laser systems for processing materials become an integral part of any high-tech production.

High-tech lasers can significantly increase labour productivity, qualitatively reduce energy consumption, are environmentally friendly equipment. Moreover, the laser beam allows to obtain qualitatively new results (precision machining, hardening of materials) compared with traditional equipment. The lamp-pumped solid-state lasers used to equip the production lines for the last 10-15 years, along with the above-mentioned advantages, have significant drawbacks: high power consumption (low efficiency), large dimensions and weight, and a short service life.

The parameters of the developed LA and the results of their life tests are given in the article.

\section{LA CHARACTERISTICS}

The report submits the results of the development of new-generation energy-efficient injection LA for systems of continuous optical pumping of solid-state lasers with a generation wavelength of $808 \mathrm{~nm}$, a maximum power conversion efficiency of $55 \%$ and an output optical power of up to 100 watts.

LAs provide, at a temperature of $25^{\circ} \mathrm{C}$, the following basic parameters, presented in Table 1.

LAs are a source of laser radiation with a narrow spectral line (3-4 nm). The main differences of the LAs are their high efficiency of converting electric current to light (more than 50\%) and small geometrical dimensions. The chips are manufactured based on heterostructures grown by metal organic chemical vapour deposition (MOCVD) epitaxy. This method of growth of heterostructures allows to control the chemical composition and thickness of the grown semiconductor layers with 
Таблица 1. Основные параметры ЛЛ

Table 1. Main LA parameters

\begin{tabular}{|c|c|}
\hline $\begin{array}{l}\text { Наименование параметра } \\
\text { Parameter }\end{array}$ & $\begin{array}{l}\text { Значение } \\
\text { Value }\end{array}$ \\
\hline $\begin{array}{l}\text { Режим работы } \\
\text { Operation mode }\end{array}$ & $\begin{array}{l}\text { Непрерывный } \\
\text { Continuous wave }\end{array}$ \\
\hline $\begin{array}{l}\text { Выходная оптическая мощность излу- } \\
\text { чения, Вт, не менее } \\
\text { Output optical power of radiation, W, } \\
\text { not less than }\end{array}$ & 100 \\
\hline $\begin{array}{l}\text { Рабочий ток, А, не более } \\
\text { Operating current, A, not more than }\end{array}$ & 125 \\
\hline $\begin{array}{l}\text { Рабочее напряжение, В, не более } \\
\text { Operating voltage, V, not more than }\end{array}$ & 2,5 \\
\hline $\begin{array}{l}\text { Ширина излучающей площадки, мм, } \\
\text { не более } \\
\text { Emitting area width, mm, not more than }\end{array}$ & 12 \\
\hline $\begin{array}{l}\text { Длина волны излучения, нм } \\
\text { Radiation wavelength, nm }\end{array}$ & $808 \pm 10$ \\
\hline $\begin{array}{l}\text { Ширина линии излучения по уровню } \\
0.5 \text {, нм, не более } \\
\text { Line width of radiation at a level of } \\
0.5 \mathrm{~nm} \text {, no more than }\end{array}$ & 5 \\
\hline $\begin{array}{l}\text { КПД,\%, не менее } \\
\text { Efficiency,\%, not less than }\end{array}$ & 55 \\
\hline
\end{tabular}

нм). Основные отличия ЛЛ - высокая эффективность преобразования электрического тока в свет (более 50\%) и малые геометрические размеры. Чипы изготавливаются на основе гетероструктур, полученных методом газофазной эпитаксии из металлорганических соединений. Этот метод роста гетероструктур позволяет с высокой точностью контролировать химический состав и толщины выращиваемых полупроводниковых слоев, обеспечивая высокую воспроизводимость параметров, что дает возможность существенно снизить рабочий ток, повысить КПД и достичь высоких значений оптической мощности излу чения. На основе прогрессивных постростовых технологий специалистами АО "Полупроводниковые приборы" разработан высокопродуктивный технологический цикл производства ЛЛ.

При выборе гетероструктуры для создания ЛЛ был проведен анализ гетероструктур, используемых для создания одиночных лазерных диодов, излучающих на длине волны 808 нм. На сегодняшний день существует два подхода для создания эпитаксиальных наноструктурированных гетероструктур (ЭНГС) раздельного ограничения: high accuracy, providing high reproducibility of parameters, which makes it possible to significantly reduce the operating current, increase efficiency and achieve high values of optical radiation power. Based on advanced post-growth technologies, the specialists of JSC "Semiconductor devices" have developed a highly productive technological cycle of LA production.

When choosing a heterostructure to create an LA, the heterostructures used to create single laser diodes emitting at a wavelength of $808 \mathrm{~nm}$ were analysed. To date, there are two approaches to create separate-confinement epitaxial nanostructured heterostructures (ENHS):

- double separate-confinement ENHS based on aluminium-non-containing (Al-free) waveguide layers and active region [1-6];

- double separate-confinement ENHS based on aluminium-containing layers of the waveguide and the active region [1, 7-10].

The maximum achieved optical output power in single laser diodes based on double separateconfinement ENHS based on an aluminium-noncontaining solid solution system is $9.9 \mathrm{~W}$ (radiating aperture width is $100 \mu \mathrm{m}$, cavity length is $3000 \mu \mathrm{m}$ ) [6]. The maximum achieved optical output power in single laser diodes based on double separate-confinement ENHS based on an aluminium-containing system of solid solutions is $13 \mathrm{~W}$ (radiating aperture width is $100 \mu \mathrm{m}$, cavity length is $4000 \mu \mathrm{m}$ ) [9]. It should be noted that such an output optical power was obtained on a laser diode using a double separate-confinement ENHS with an ultra-wide symmetric waveguide (the total thickness of the waveguide layer is 3 $\mu \mathrm{m})$. In a laser diode based on a double separateconfinement ENHS of with a waveguide $1 \mu \mathrm{m}$ thick, the maximum power achieved is $8.9 \mathrm{~W}[10]$.

From the above, it can be concluded that single laser diodes made on the basis of aluminiumnon-containing and aluminium-containing solid solutions in the waveguide layers and the active region have approximately the same power characteristics. In terms of manufacturability, the most convenient solid solution system is AlGaAs. The advantage of the AlGaAs solid solutions system is the maximum reproducibility of the results, as well as the minimum mismatch over the lattice period with the GaAs substrate in the entire composition range (the maximum mismatch value is obtained for AlAs and is $1.18 \cdot 10^{-3}$ ), which is important for ensuring high optical characteristics of the laser diode. The disadvantages of the AlGaAs 
- двойные ЭНГС раздельного ограничения на основе алюминий-не-содержащих слоев волновода и активной области [1-6];

- двойные ЭНГС раздельного ограничения на основе алюминий-содержащих слоев волновода и активной области [1, 7-10].

Максимально достигнутая выходная оптическая мощность в одиночных лазерных диодах на основе двойных ЭНГС раздельного ограничения на основе алюминий-не-содержащей системы твердых растворов, составляет 9,9 Вт (ширина излучающей апертуры $100 \mathrm{MkM}$, длина резонатора 3000 мкм) [6]. Максимально достигнутая выходная оптическая мощность в одиночных лазерных диодах на основе двойных ЭНГС раздельного ограничения на основе алюминийсодержащей системы твердых растворов, состав ляет 13 Вт (ширина излучающей апертуры 100 мкм, длина резонатора 4000 мкм) [9]. Следует отметить, что такая выходная оптическая мощность была получена на лазерном диоде при использовании двойной ЭНГС раздельного ограничения со сверхшироким симметричным волноводом (суммарная толщина волноводного слоя 3 мкм). В лазерном диоде на основе двойной ЭНГС раздельного ограничения с волноводом толщиной 1 мкм максимально достигнутая мощность составляет 8,9 Вт [10].

Из всего вышесказанного можно сделать вывод, что одиночные лазерные диоды, изготовленные на основе алюминий-не-содержащих и алюминий-содержащих твердых растворов в волноводных слоях и активной области, имеют примерно одинаковые мощностные характеристики. С точки зрения технологичности, наиболее удобной системой твердых растворов является AlGaAs. Достоинством системы твердых растворов AlGaAs является максимальная воспроизводимость результатов, а также минимальное рассогласование по периоду решетки с подложкой GaAs во всем диапазоне составов (максимальное значение рассогласования получается для AlAs и составляет $1,18 \cdot 10^{-3}$ ), что важно для обеспечения высоких оптических характеристик лазерного диода. K недостаткам системы AlGaAs следует отнести высокую способность алюминия к окислению. Поэтому не рекомендуется использовать при создании двойных ЭНГС раздельного ограничения слои $\mathrm{Al}_{\mathrm{x}} \mathrm{Ga}_{1-\mathrm{x}}$ As с составом по алюминию (х) больше 0,6, т. к. чем больше содержание алюминия в слое, тем процесс окисления интенсивнее. Сильное окисление алюминиевых слоев может привести к ухудшению выход- system include the high oxidative ability of aluminium. Therefore, it is not recommended to use layers of $\mathrm{Al}_{\mathrm{x}} \mathrm{Ga}_{1-\mathrm{x}}$ As with a composition on aluminium (x) greater than 0.6 in the creation of double separate-confinement ENHS, since the higher the aluminium content in the layer, the more intense the oxidation process. Strong oxidation of aluminium layers can lead to deterioration of the output characteristics of laser diodes, namely: a decrease in reliability, an increase in resistance and optical losses.

Based on the above, double separateconfinement ENHS was developed based on the AlGaAs solid solution system to create LA.

When developing the design of a double separate-confinement ENHS for LA, the main objectives were: ensuring the operation of LA on a zero fundamental transverse mode of an electromagnetic wave; ensuring minimal internal optical loss in the LA waveguide; the suppression of the emission of charge carriers from the active region into the waveguide layers; ensuring minimal electrical resistance of ENHS; ensuring ENHS technological design.

For ENHS, the following layer compositions were selected: $\mathrm{Al}_{0,55} \mathrm{Ca}_{0,45} \mathrm{As}$ emitter layer; $\mathrm{Al}_{0,37} \mathrm{Ca}_{0,63} \mathrm{As}$ waveguide layer; the active region is an $\mathrm{Al}_{0,1} \mathrm{Ga}_{0,9}$ As quantum well with a thickness of $12 \mathrm{~nm}$.

To ensure the operation of the LA at the zerotransverse mode of the electromagnetic wave and the minimum internal optical loss, the distribution profiles of the electromagnetic wave in the waveguide were calculated using the model proposed in [11]. To meet these requirements, we used an extended waveguide $(1.5 \mu \mathrm{m})$. A feature of working with a wide waveguide is the need to calculate at least two more higher order modes. Suppression of these modes can be achieved by maximizing the optical losses and minimizing their modal amplification. To suppress higher order modes, an asymmetric waveguide is used with a shift of the active region towards the P-emitter.

Fig. 1 shows the results of calculating the distribution of modes of different orders of an electromagnetic wave. Table 1 presents the parameters of the calculated ENHS.

For testing the LA manufacturing technology, the optimum technological scheme of the assembly was chosen, which allows to obtain LA with an output optical power up to $100 \mathrm{~W}$ operating in a continuous mode at the final stage as finished products. 
ных характеристик лазерных диодов, а именно: уменьшению надежности, увеличению сопротивления и оптических потерь.

На основании вышесказанного была разработана для создания ЛЛ двойная ЭНГС раздельного ограничения на основе системы твердых растворов AlGaAs.

При разработке конструкции двойной ЭНГС раздельного ограничения для ЛЛ основными целями были: обеспечение работы лл на нулевой поперечной моде электромагнитной волны; обеспечение минимальных внутренних оптических потерь в волноводе Лл; подавление выброса носителей заряда из активной области в волноводные слои; обеспечение минимального электрического сопротивления ЭНГС; обеспечение технологичности конструкции ЭНГС.

Для ЭНГС были выбраны следующие составы слоев: эмиттерный слой $\mathrm{Al}_{0,55} \mathrm{Ga}_{0,45} \mathrm{As}$; волноводный слой $\mathrm{Al}_{0,37} \mathrm{Ga}_{0,63} \mathrm{As}$; активная область - КЯ $\mathrm{Al}_{0,1} \mathrm{Ga}_{0,9}$ As толщиной 12 нм .

Для обеспечения работы лл на нулевой поперченной моде электромагнитной волны и минимальных внутренних оптических потерь был проведен расчет профилей распределения электромагнитной волны в волноводе по модели, предложенной в [11]. Для обеспечения этих требований нами использовался расширенный волновод (1,5 мкм). Особенностью работы с широким волноводом является необходимость расчета по меньшей мере еще двух мод высшего порядка. Подавления этих мод можно добиться за счет максимизации оптических потерь и минимизации модального усиления для них. Для подавления мод высшего порядка используют асимме-

Таблица 2. Рассчитанные параметры ЭНГС Table 2. Design ENHS parameters

\begin{tabular}{|c|c|c|c|}
\hline $\begin{array}{l}\text { № } \\
\text { №. }\end{array}$ & $\begin{array}{l}\text { Название } \\
\text { Parameter }\end{array}$ & $\begin{array}{l}\text { Состав } \\
\text { Composition }\end{array}$ & $\begin{array}{l}\text { Легирование } \\
\text { Doping }\end{array}$ \\
\hline 1 & $\begin{array}{l}\text { N-эмиттер } \\
\text { N-emitter }\end{array}$ & $\mathrm{Al}_{0,55} \mathrm{Ga}_{0,45} \mathrm{As}$ & $\begin{array}{l}\mathrm{N} \text {-тип } \\
\mathrm{N} \text {-tуре }\end{array}$ \\
\hline 2 & $\begin{array}{l}\mathrm{N} \text {-волновод } \\
\mathrm{N} \text {-waveguide }\end{array}$ & $\mathrm{Al}_{0,37} \mathrm{Ga}_{0,63} \mathrm{As}$ & $\begin{array}{l}\text { Нелегирован } \\
\text { Undopped }\end{array}$ \\
\hline 3 & $\begin{array}{l}\text { КЯ } \\
\text { Quantum well }\end{array}$ & $\mathrm{Al}_{0,1} \mathrm{Ga}_{0,9} \mathrm{As}$ & $\begin{array}{l}\text { Нелегирован } \\
\text { Undopped }\end{array}$ \\
\hline 4 & $\begin{array}{l}\text { Р-волновод } \\
\text { P-waveguide }\end{array}$ & $\mathrm{Al}_{0,37} \mathrm{Ga}_{0,63} \mathrm{As}$ & $\begin{array}{l}\text { Нелегирован } \\
\text { Undopped }\end{array}$ \\
\hline 5 & $\begin{array}{l}\text { P-эмиттер } \\
\text { P-emitter }\end{array}$ & $\mathrm{Al}_{0,55} \mathrm{Ga}_{0,45} \mathrm{As}$ & $\begin{array}{l}\text { P-тип } \\
\text { P-type }\end{array}$ \\
\hline
\end{tabular}

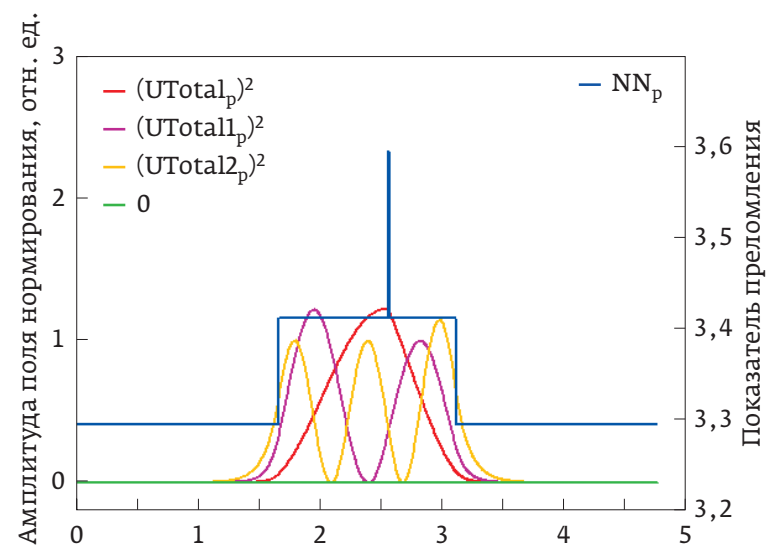

Координата от поверхности гетероструктуры, мкм

Puc. 1. Расчетное распределение поля электромагнитной волны в волноводе алюминий содержащей двойной эпитаксиальной наноструктурированной гетероструктуры раздельного ограничения для мод разных порядков Fig. 1. Designed distribution of the electromagnetic wave field in an aluminium waveguide containing a double separateconfinement epitaxial nanostructured heterostructure for modes of different orders

The construction of the technological scheme for carrying out assembly operations in the manufacture of LA is based on a certain basic concept:

- high reproducibility of technological process characteristics;

- possibility of carrying out several technological processes in one reaction chamber without opening;

- possibility of easy adjustment modes when changing the parameters of technological processes;

- constant technological control over the quality of technological operations;

- $\quad$ ease of retrofitting and maintenance of the equipment used;

- possibility of making adjustments and improving the technological scheme;

- minimal environmental impact during the process.

The installation of LA chips on the heat sink was carried out by the method of flux-free soldering through a buffer plate (submount) made of $\mathrm{CuW}(80 / 20)$. The installation of the insulating plate on the heat sink was carried out to ensure electrical isolation between the LA conductive contacts. As the material of the plate, the $\mathrm{Al}_{2} \mathrm{O}_{3}$ ceramic plate (polycor) metallized on one side, 
тричный волновод со сдвигом активной области к Р-эмиттеру.

На рис. 1 приведены результаты расчета распределения мод различных порядков электромагнитной волны. В табл. 2 представлены параметры рассчитанной ЭНГС.

Для отработки технологии изготовления ЛЛ была выбрана оптимальная технологическая схема сборки, позволяющая на финишной стадии в качестве готовой продукции получать ЛЛ с выходной оптической мощностью до 100 ВТ, работающие в непрерывном режиме.

Построение технологической схемы по проведению сборочных операций при изготовлении ЛЛ основано на определенной базовой концепции:

- высокая воспроизводимость характеристик технологических процессов;

- возможность проведения нескольких технологических процессов в одной реакционной камере без ее вскрытия;

- возможность легкой перестройки режимов при изменении параметров технологических процессов;

- постоянный технологический контроль за проведением качества производимых технологических операций;

- простота переоснастки и обслуживания используемого оборудования;

- возможность осуществления корректировки и совершенствования технологической схемы;

- минимальное воздействие окружающей среды при проведении технологического процесса.

Монтаж чипов ЛЛ на теплоотвод осуществлялся методом бесфлюсовой пайки через буферную пластину (сабмаунт) из $\mathrm{CuW}(80 / 20)$. Монтаж изолирующей пластины на теплоотвод проводился для обеспечения электрической развязки между токопроводящими контактами ЛЛ. В качестве мате-
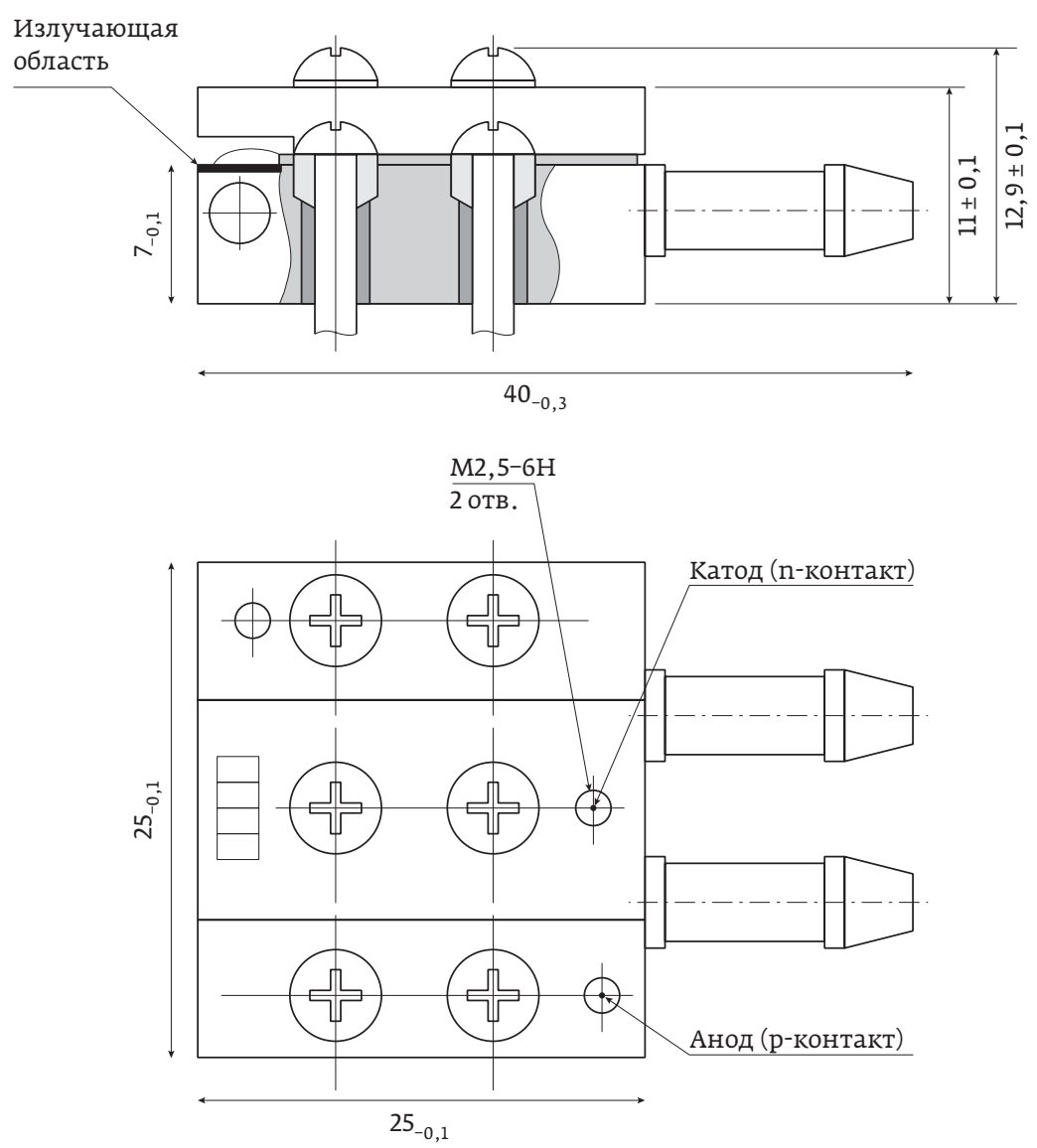

Puс. 3. Габаритный чертеж Лл на водоохпаждаемом теплоотводе Fig. 3. Dimensional drawing of LA on a water-cooled heat sink 


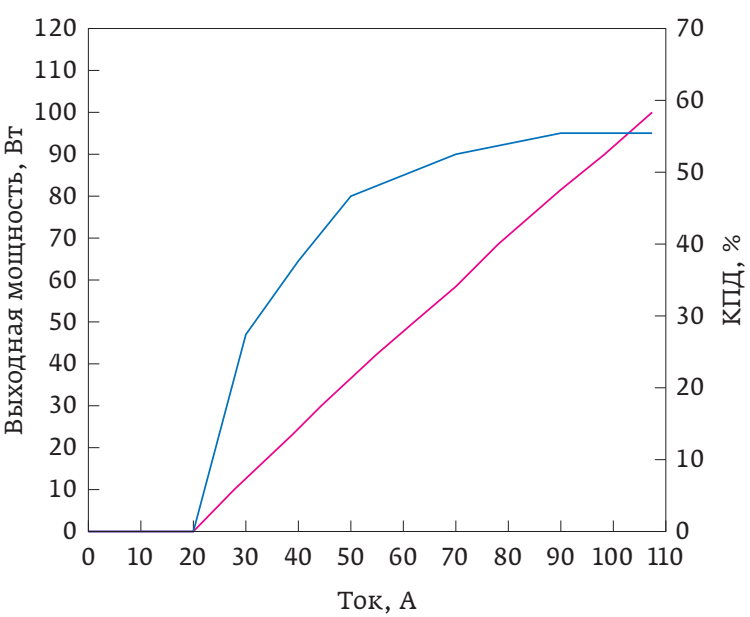

Puc. 4. Типичная зависимость выходной оптической мощности от тока накачки и КПД ЛЛ

Fig. 4. Typical dependence of the output optical power on the pump current and LA efficiency

риала пластины использовалась металлизированная с одной стороны керамическая пластина $\mathrm{Al}_{2} \mathrm{O}_{3}$ (поликор), обладающая высокими изоляционными свойствами и имеющая достаточно хорошую теплопроводность.

Для измерения выходной оптической мощности ЛЛ использовался калиброванный болометрический измеритель фирмы Ophir.

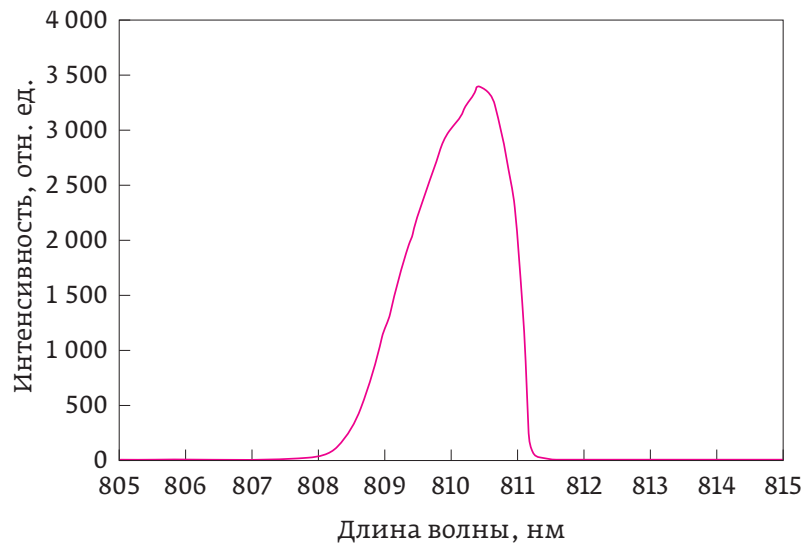

Puc. 5.Типичный спектр ЛЛ

Fig. 5. Typical LA spectrum

Spectral measurements were performed using an ASP-150TF fibre optic spectrometer.

Fig. 2 shows the appearance of LA on a watercooled heat sink. Fig. 3 shows the dimensional drawing of LA on a water-cooled heat sink. Fig. 4 shows the typical dependence of the output optical power on the pump current and the efficiency of the LA. As the analysis of dependence shows, the maximum efficiency of LA reaches $55 \%$, at a temperature of TO LA $+25^{\circ} \mathrm{C}$.

Fig. 5 shows a typical LA spectrum. The narrow spectral emission band of $-3-4 \mathrm{~nm}$ indicates a high
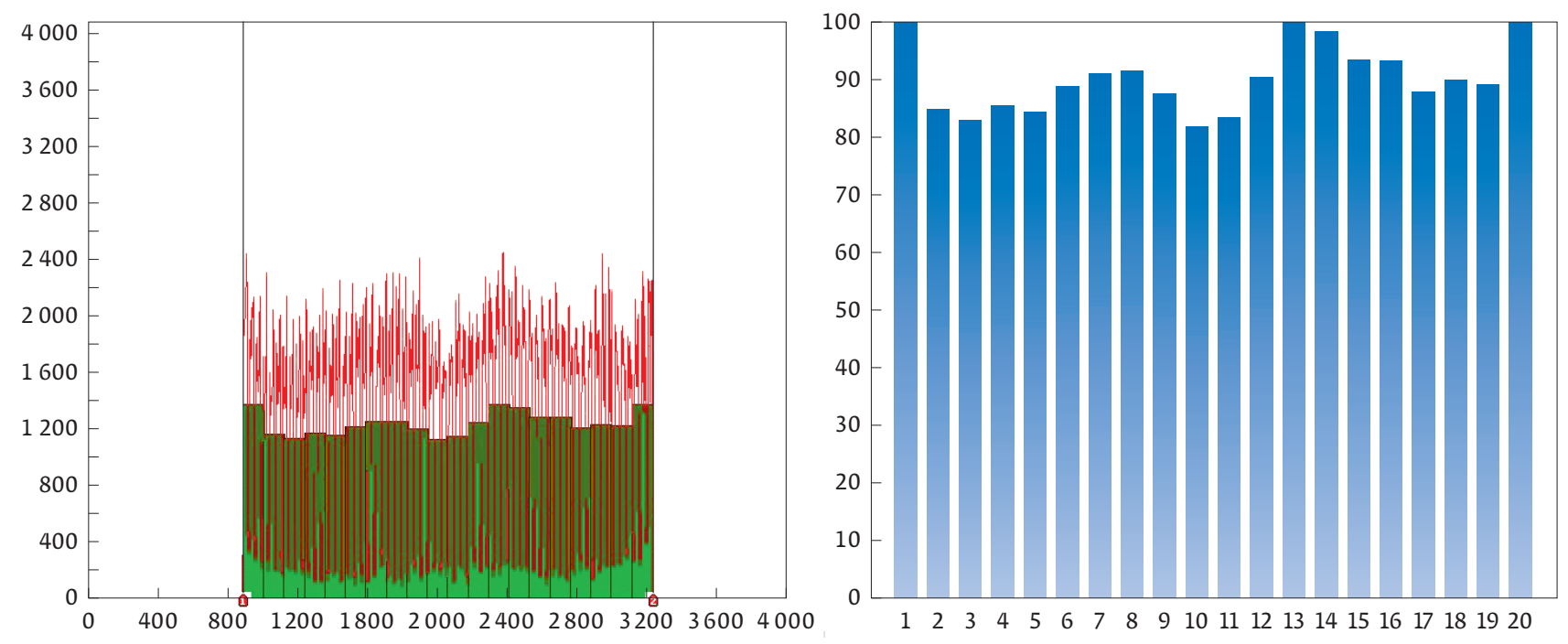

Puc. 6. Распределение оптической мощности по полосковым излучателям ЛЛ

Fig. 6. Distribution of optical power on the LA strip emitters 
Спектральные измерения проводились с использованием оптоволоконного спектрометра ASP-150TF.

На рис. 2 представлен внешний вид Лл на водоохлаждаемом теплоотводе. На рис. 3 представлен габаритный чертеж ЛЛ на водоохлаждаемом теплоотводе. На рис. 4 представлена типичная зависимость выходной оптической мощности от тока накачки и КПд лЛ. Как показывает анализ зависимости, максимальный КПд ЛЛ достигает 55\% при температуре ТО ЛЛ $+25^{\circ} \mathrm{C}$.

На рис. 5 представлен типичный спектр Лл. Узкая спектральная полоса излучения -3-4 нм говорит о высокой однородности и качестве монтажа чипов ЛЛ. Распределение оптической мощности по полосковым излучателям (рис. 6) показывает высокую однородность по всей ширине излучающей площадки, что подтверждает качество гетероструктуры и высокую технологичность всех постростовых процессов изготовления ЛЛ.

Разработанные Лл подвергались ресурсным испытаниям в режиме поддержания постоянной величины тока накачки, равного 115-117А

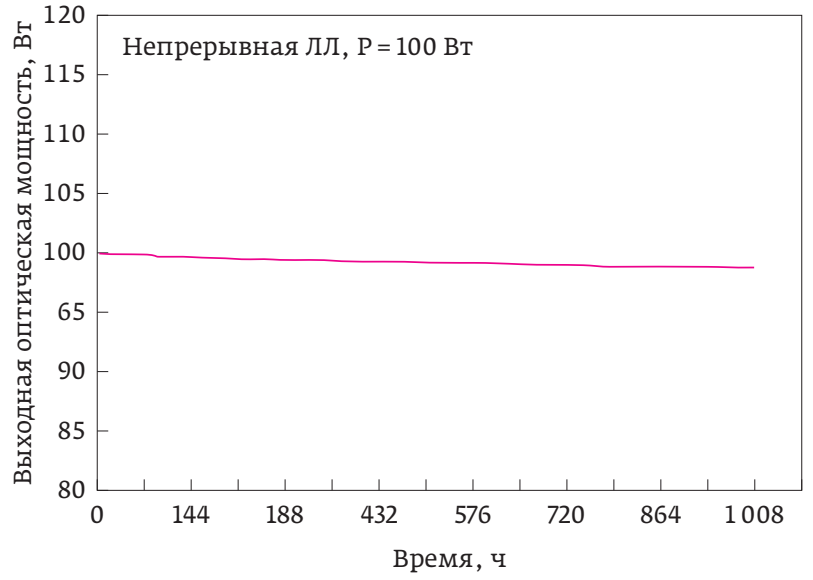

Puс. 7. Зависимость изменения выходной мощности ЛЛ от времени наработки

Fig. 7. Dependence of the LA output power on the operating time

homogeneity and quality of mounting of LA chips. The distribution of optical power over the strip emitters (Fig. 6) shows a high homogeneity across the entire width of the radiating platform, which

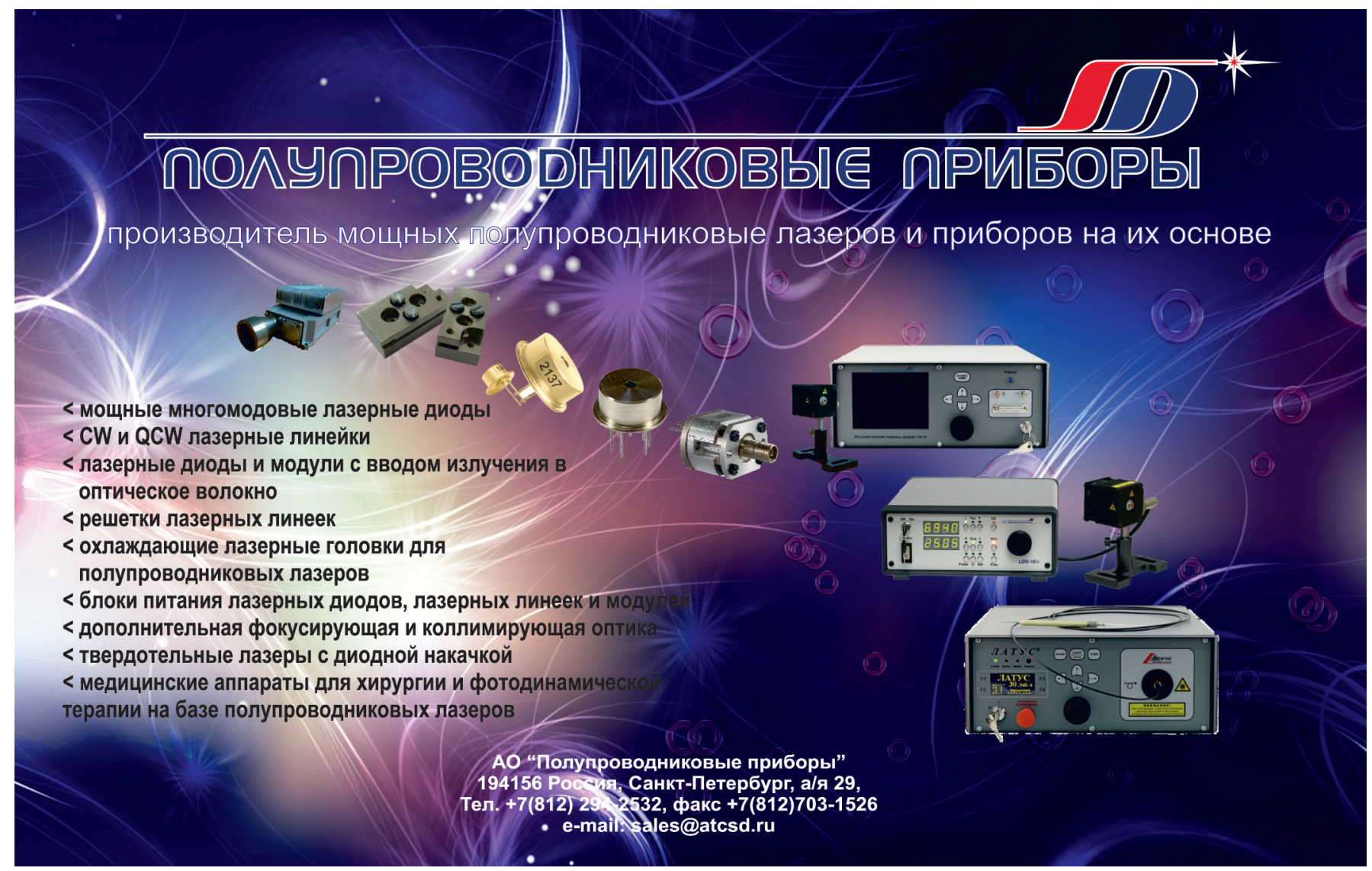




\section{LASERS \& LASER SYSTEMS}

(с номинальной выходной мощностью 100 Вт). При температуре ТО лл $+25{ }^{\circ} \mathrm{C}$ в течение 1000 часов падение выходной оптической мощности составило не более $1,5 \%$. Таким образом, по линейной экстраполяции временной зависимости можно оценить ожидаемый ресурс работы лЛ при Т = +25 как 10000 часов .

На рис. 7 представлена зависимость изменения выходной мощности ЛЛ от времени наработки.

\section{ЗАКЛЮЧЕНИЕ}

Таким образом, в настоящей работе были разработаны и исследованы мощные высокоэффективные непрерывные ЛЛ, предназначенные для накачки твердотельных лазеров на основе ионов $\mathrm{Nd}^{+}$.

\section{БЛАГОДАРНОСТИ}

Работы выполнялись в соответствии с Программой Союзного государства России и Беларуси "Разработка критических стандартных техноло гий проектирования и изготовления изделий наноструктурной микро- и оптоэлектроники, приборов и систем на их основе и оборудования для их производства и испытаний" - СЧ ОКР "Разработка параметрических рядов мощных фотодиодов СВЧ-диапазона, а также конструктивно и технологически подобных энергоэффективных инжекционных лазеров нового поколения в части изготовления эпитаксиальных наноструктурированных гетероструктур, разделения на чипы энергоэффективных инжекци онных лазеров, нанесения защитных покрытий на зеркала чипов энергоэффективных инжекционных лазеров и сборки энергоэффективных инжекционных лазеров, системы оптической диодной накачки для высокоэнергетичного, полностью твердотельного лазера и полностью твердотельного лазера для промышленности, энергетики и специальных применений" шифр СЧ ОКР «Луч-3.2.1».

\section{СПИСОК ЛИТЕРАТУРЫ}

1. Безотосный В. В., Васильева В. В., Винокуров Д.А., Капитонов В. А., Крохин О. Н., Лешко А. Ю., Лютецкий А. В., Мурашова А. В., Налет Т. А., Николаев Д. Н., Пихтин Н. А., Попов Ю. М., Слипченко С. О., Станкевич А. Л., Фетисова Н. В., Шамахов В. В., Тарасов И.С. Мощные лазерные диоды с длиной волны излучения 808 нм на основе различных типов асимметричных гетероструктур со сверхшироким волноводом. Физика и техника попупроводников. 2008; 42 (3):357-360.

2. Алуев А. В., Лешко А. Ю., Лютецкий А. В., Пихтин Н. А., Слипченко С. О., Фетисова Н. В., Чельный А. А., Шамахов В. В., Симаков В. А., Тарасов И. С. GalnAsP / GalnP / AlGalnP-лазеры, излучающие на длине волны 808 нм, выращенные методом МОС-гидридной эпитаксии. Физика и техника полупроводников. 2009; 43(4): 556-560. confirms the quality of the heterostructure and you low manufacturability of all post-production processes of LA.

The developed LAs were subjected to life tests in the mode of maintaining a constant pump current of 115-117A (with a nominal output power of $100 \mathrm{~W}$ ). At a temperature of $\mathrm{LA}+25^{\circ} \mathrm{C}$ for 1.000 hours, the drop of the output optical power was no more than $1.5 \%$. Thus, by linear extrapolation of the time dependence, it is possible to estimate the expected life of the LA at T $=+25^{\circ} \mathrm{C}$ as 10,000 hours.

Fig. 7 shows the dependence of the LA output power on the operating time.

\section{CONCLUSION}

Thus, the powerful high-efficiency continuous LA designed for pumping solid-state lasers based on $\mathrm{Nd}^{+}$ions were developed and investigated in this paper.

\section{ACKNOWLEDGMENTS}

The work was carried out in accordance with the Program of the Union State of Russia and Belarus "Development of critical standard technologies for designing and manufacturing nanostructured micro and optoelectronics products, devices and relating systems, and equipment for their production and testing" - Composite Part of Research and Development Work "Development of parametric rows of high-power microwave photodiodes, as well as structurally and technologically similar new-generation energy-efficient injection lasers in the manufacture of epitaxial nanostructured heterostructures, energy-efficient injection lasers chip separation, application of protective coatings on mirrors of energy-efficient injection lasers and assembly of energy-efficient injection lasers, systems optical diode pumping for a high-energy all-solid-state laser and fully solid-state laser for industry, energy and special applications" code of the Composite Part of Research and Development Work is "Luch-3.2.1".

\section{REFERENCE}

1. Bezotosnyī V. V., Vasileva V. V., Vinokurov D. A.,. Kapitonov V. A., Krokhin O. N., Leshko A. Yu., Lyutetskii A. V., Murashova A. V., Nalet T. A., Nikolaev D. N., Pikhtin N. A., Popov Yu. M., Slipchenko S. O. Stankevich A. L., Fetisova N. V., Shamakhov V. V., Tarasov I. S. High-power laser diodes of wavelength $808 \mathrm{~nm}$ based on various types of asymmetric heterostructures with an ultrawide waveguide. Semiconductors. 2008; 42 (3):357-360.

2. Aluev A. V., Leshko A. Yu., Lyuteckij A. V., Pihtin N. A., Slipchenko S. O., Fetisova N.V., Chel'nyj A.A., Shamahov V. V., Simakov V. A., Tarasov I. S. GalnAsP / GalnP / AlGaInP MOCVD-grown diode lasers emitting at $808 \mathrm{~nm}$. Semiconductors. 2009; 43(4): 532-536.

3. Eliashevich I., Diaz J., Yi H., Wang L., Razeghi M. Reliability of alu- 
3. Eliashevich I., Diaz J., Yi H., Wang L., Razeghi M. Reliability of aluminium-free $808 \mathrm{~nm}$ high-power laser diodes with uncoated mirrors. Applied Physics Letters. 1995; 66(23): 3087-3089.

4. Wang L. J., Wu S. L., Diaz J., Eliashevich I., Yi H. J., Razeghi M. Operating characteristics of Al-free InCaAsP / GaAs single quantum well high-power laser. Proceedings SPIE. 1996; 2886:114-117.

5. Peixu Li, Ling Wang, Shuqiang Li, Wei Xia, Xin Zhang, Oingmin Tang, Zhongxiang Ren, Xiangang Xu. MOCVD growth of AIGaInP / GaInP quantum well laser diode with asymmetric cladding structure for high power applications. Chinese Optics Letters. 2009; 7 (6): 489-491.

6. Diaz J., Yi H., Razeghi M., Burnham G. T. Long-term reliability of Al-free InCaAsP / GaAs $(\lambda=808 \mathrm{~nm})$ lasers at high-power high-temperature operation. Applied Physics Letters. 1997; 71(21): 3042-3044.

7. Андреев А. Ю., Зорина С. А., Лешко А. Ю., Лютецкий А. В., Мармалюк А.А., Мурашова А. В., Налет Т. А., Падалица А. А., Пихтин Н.А., Сабитов Д. Р., Симаков В.А., Слипченко С. О., Телегин К. Ю., Шамахов В. В., Тарасов И. С. Мощные лазеры $(\lambda=808$ нм) на основе гетероструктур раздельного ограничения AlGaAs / GaAs. Физика и техника поnупроводников. 2009; 43(4): 453-457.

8. Jensena O.B., Klehrb A., Dittmarb F., Sumpfb B., Erbertb G., Andersena P. E., Petersen P. M. $808 \mathrm{~nm}$ tapered diode lasers optimised for high output power and nearly diffraction-limited beam quality in pulse mode operation. Proceedings SPIE. 2007; 6456: 64560A-1-64560A-10.

9. Knauer A., Erbert G., Staske R., Sumpf B., Wenzel H., Weyers M. Highpower $808 \mathrm{~nm}$ lasers with a super-large optical cavity. Semiconductor Science and Technology. 2005; 20: 621-624.

10. Sebastian J., Beister G., Bugge F., Buhrandt F., Erbert G., Hansel H. G. Hulsewede R., Knauer A., Pittroff W., Staske R., Schroder M., Wenzel H., Weyers M., Trankle G. High-Power 810-nm GaAsP-AlGaAs Diode Lasers With Narrow Beam Divergence. IEEE Journal on Selected Topics in Quantum Electronics. 2001; 7(2):334-339.

11. Coldren L. A., Corzine S. W., Mashanovitch M. L. Diode Lasers and Photonic Integrated Circuits. Wiley. 2012. minium-free $808 \mathrm{~nm}$ high-power laser diodes with uncoated mirrors. Applied Physics Letters. 1995; 66(23): 3087-3089.

4. Wang L. J., Wu S. L., Diaz J., Eliashevich I., Yi H. J., Razeghi M. Operating characteristics of Al-free InCaAsP / GaAs single quantum well high-power laser. Proceedings SPIE. 1996; 2886:114-117.

5. Peixu Li, Ling Wang, Shuqiang Li, Wei Xia, Xin Zhang, Qingmin Tang, Zhongxiang Ren, Xiangang Xu. MOCVD growth of AlGaInP / GalnP quantum well laser diode with asymmetric cladding structure for high power applications. Chinese Optics Letters. 2009; 7 (6): 489-491.

6. Diaz J., Yi H., Razeghi M., Burnham C. T. Long-term reliability of Alfree InCaAsP / GaAs $(\lambda=808 \mathrm{~nm})$ lasers at high-power high-temperature operation. Applied Physics Letters. 1997; 71(21): 3042-3044.

7. Andreev A. Yu., Zorina S. A., Leshko A. Yu., Lyuteckij A. V., MarmaIyuk A. A., Murashova A. V., Nalet T. A., Padalica A. A., Pihtin N. A., Sabitov D. R., Simakov V. A., Slipchenko S. O., Telegin K. Yu., Shamahov V. V., Tarasov I. S. High-power lasers $(\gamma=808 \mathrm{~nm})$ based on the AIGaAs / GaAs heterostructures of separate confinement. Semiconductors. 2009; 43(4): 519-523.

8. Jensena O. B., Klehrb A., Dittmarb F., Sumpfb B., Erbertb G., Andersena P. E., Petersen P. M. 808 nm tapered diode lasers optimised for high output power and nearly diffraction-limited beam quality in pulse mode operation. Proceedings SPIE. 2007; 6456: 64560A-1-64560A-10.

9. Knauer A., Erbert G., Staske R., Sumpf B., Wenzel H., Weyers M. High-power $808 \mathrm{~nm}$ lasers with a super-large optical cavity. Semiconductor Science and Technology. 2005; 20: 621-624.

10. Sebastian J., Beister G., Bugge F., Buhrandt F., Erbert G., Hansel H. G., Hulsewede R., Knauer A., Pittroff W., Staske R., Schroder M., Wenzel H., Weyers M., Trankle G. High-Power 810-nm GaAsPAIGaAs Diode Lasers With Narrow Beam Divergence. IEEE Journal on Selected Topics in Quantum Electronics. 2001; 7(2):334-339.

11. Coldren L. A., Corzine S. W., Mashanovitch M. L. Diode Lasers and Photonic Integrated Circuits. Wiley. 2012

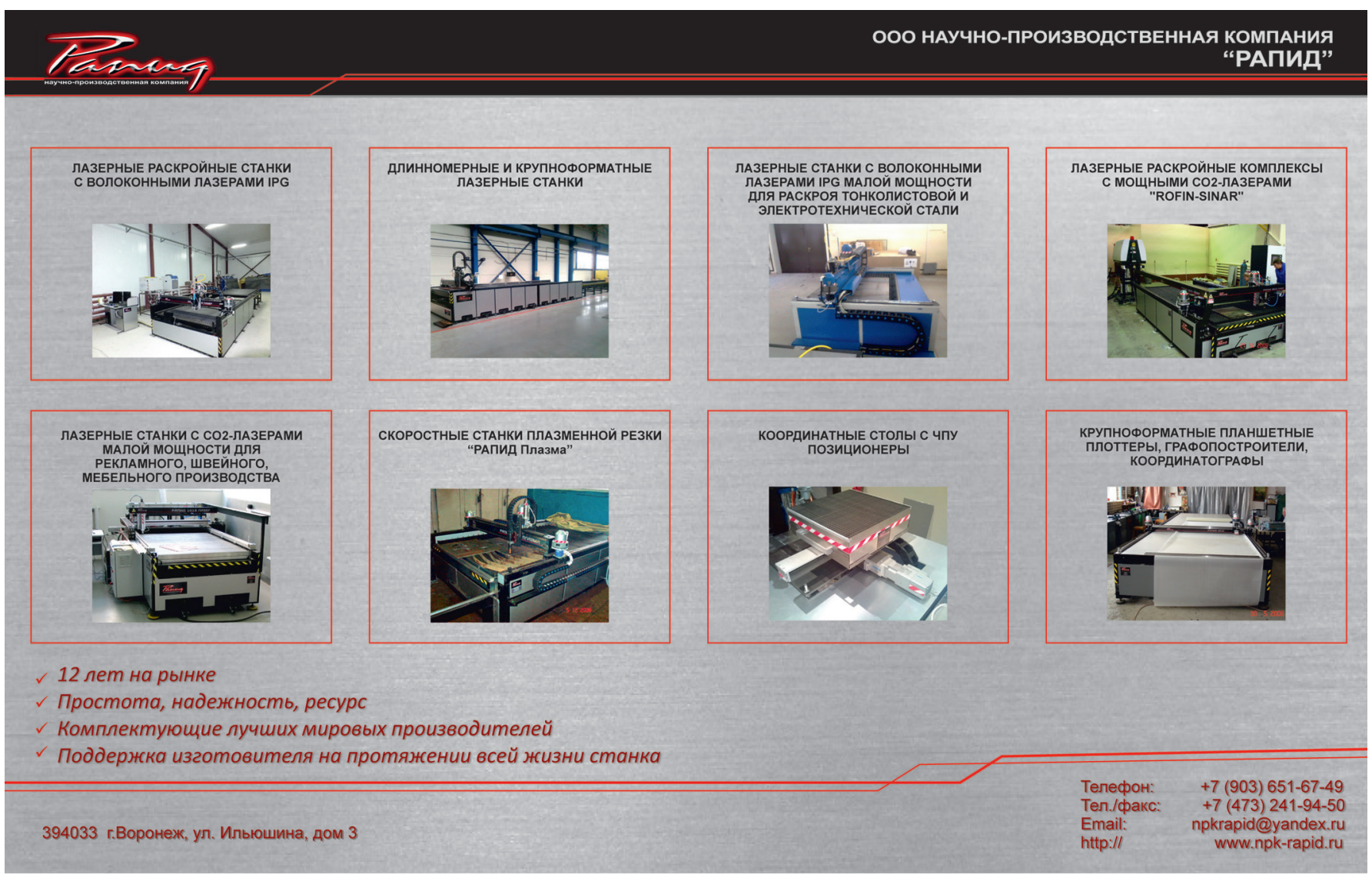

